\title{
Linking human resources practices to employee engagement in the hospitality industry: the mediating influences of psychological safety, availability and meaningfulness
}

\author{
Md Karim Rabiul
}

Faculty of Hospitality and Tourism, Prince of Songkla University - Phuket Campus, Phuket, Thailand

Ahmad Edwin Mohamed

School of Tourism, Hospitality and Event Management, Universiti Utara Malaysia,

Sintok, Malaysia

Ataul Karim Patwary

Faculty of Hospitality, Tourism and Wellness, Universiti Malaysia Kelantan,

Kota Bharu, Malaysia

Tan Fee Yean

School of Business Management, Universiti Utara Malaysia,

Sintok, Malaysia, and

Siti Zaitun Osman

Administrative Science and Policy Studies, Universiti Teknologi MARA,

Melaka, Malaysia

\begin{abstract}
Purpose - Drawing on self-concept theory, this study evaluates the mediating effects of employees' psychological states on the relationship between human resources (HR) practices and employee engagement. Design/methodology/approach - Through random sampling, 434 customer-contact frontline employees from five-star hotels in Malaysia participated in the cross-sectional survey.

Findings - The results produced by the Smart-PLS (partial least squares) indicate that HR practices positively and significantly influence employees' psychological states of safety, meaningfulness and availability. All these psychological states also exert positive influences on employee engagement (organisational and work engagement). Safety and availability mediate the links between HR practices and employee engagement, but not meaningfulness.

Practical implications - HR practices and employees' psychological states are necessary in ensuring positive employee outcomes and improving customer service provision.

Originality/value - The findings contribute to the further extension of self-concept theory and employee engagement by incorporating the mediating roles of employees' psychological states in the relationships between HR practices and employee engagement.
\end{abstract}

Keywords Human resource practices, Meaningfulness, Safety, Availability, Work engagement,

Organisational engagement

Paper type Research paper

(C) Md Karim Rabiul, Ahmad Edwin Mohamed, Ataul Karim Patwary, Tan Fee Yean and Siti Zaitun Osman. Published in European Journal of Management and Business Economics. Published by Emerald Publishing Limited. This article is published under the Creative Commons Attribution (CC BY 4.0) licence. Anyone may reproduce, distribute, translate and create derivative works of this article (for both commercial and non-commercial purposes), subject to full attribution to the original publication and authors. The full terms of this licence may be seen at http://creativecommons.org/licences/by/4.0/legalcode

Linking human resources practices

Received 7 December 2020 Revised 31 May 2021 12 August 2021

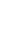




\section{Introduction}

Highly engaged employees often result in reduced turnover intention, better customer service delivery, improved financial performance, decreased job stress and increased psychological well-being (Harter et al., 2020; Memon et al., 2020). Despite the importance of employee engagement, only 15\% of employees are engaged worldwide (Harter and Rubenstein, 2020), including 19\% in Southeast Asia countries such as Malaysia (Gallup, 2017). The hospitality industry in Malaysia contributes to the country's gross domestic product consistently: it was the third largest in foreign revenue earnings with 86.1bn in 2019 (The Star, 2019; Trading Economics, 2020). As such, it is imperative to focus on increasing employee engagement, especially among frontline customer-contact employees who significantly affect the success of the hotel industry owing to their direct and frequent interactions with customers (Rabiul et al., 2021; Rabiul and Yean, 2021).

To increase employee engagement, studies have shown that human resource (HR) practices and employees' psychological states play significant roles (Alfes et al., 2020; Guan and Frenkel, 2018; Memon et al., 2020; Zhang et al., 2018). Several studies have identified that HR practices influence employee engagement using different mediating mechanisms such as psychological empowerment, organisational commitment, job satisfaction and psychological capital (Aktar and Pangil, 2018; Huang et al., 2017; Karadas and Karatepe, 2019). Although these studies contributed to the employee engagement literature, a few gaps remain unexplored.

First, the existing studies failed to systematically investigate the effects of $\mathrm{HR}$ practices on employees' psychological states (meaningfulness, safety, availability) which lead to greater employee engagement. Although different psychological states exist (e.g. Hyland, 1990: Kahn, 1990; Rabiul et al., 2021) in the literature, we investigate Kahn's (1990) three psychological states as mediators between HR practices and employee engagement. Kahn (1990) showed the importance of psychological states by stating, "people employ and express or withdraw and defend their preferred selves on the basis of their psychological experiences of self-in-role" (p. 702). Moreover, prior studies claimed that psychological states of meaningfulness, safety and availability are the underlying mechanisms to increase positive outcomes among employees (Basit, 2017; Chen et al., 2016a; Fletcher, 2016; Wang et al., 2019). Self-concept theory (Aryee et al., 2012; Rabiul et al., 2021) suggests that individuals will generate positive feeling in the workplace when they receive the necessary support from organisations. As such, when HR practices from the organisations are available, employees will experience positive psychological states of availability, safety and meaningfulness of work. Consequently, employees will express positive attitudes towards their work roles (work engagement) and organisations (organisational engagement).

Second, earlier studies focussed primarily on increasing employees' work engagement (Guan and Frenkel, 2018; Karadas and Karatepe, 2019; Memon et al., 2020; Zhang et al., 2018), while ignoring organisational engagement (Fletcher and Schofield, 2019). As employees need to perform multiple roles in the organisation, both organisational and work engagements are important (Saks, 2006, 2017). According to Saks (2017), work engagement is "the relationship between an employee and his or her job' and organisational engagement is an 'individual's' role, responsibility, and tasks associated with one's membership in an organisation" (p. 79). Limited studies (e.g. May et al., 2004) have examined three psychological states together to understand the importance of these states in engaging employees at work. Therefore, delineating on self-concept theory (Rabiul et al., 2021), the present research examines the mediating effects of an employee's perceived psychological states (e.g. meaningfulness, safety and availability) on the relationship between $\mathrm{HR}$ practices and employee engagement (work and organisational engagement) in the hotel industry in Malaysia.

This study adds value to the literature in two ways. First, it enriches self-concept theory and employee engagement by investigating the mediating influence of employees' three 
psychological states between HR practices and employee engagement. Second, the findings contribute to the hospitality literature on engaging employees through good $\mathrm{HR}$ practices and improving employees' psychological feeling of meaningfulness, safety and availability at one's workplace.

\section{Literature review}

Employee engagement

Kahn was the first scholar who introduced the term "work engagement" in 1990 (May et al., 2004; Saks, 2006). According to Kahn (1990), personal engagement or employee engagement was defined as "the simultaneous employment and expression of a person's 'preferred self' in the task behaviours that promote engagement to work and to others, personal presence (physical, cognitive, and emotional), and active, full role performance" (p. 700). Since then, employee engagement has attracted the attention of many business organisations and academicians. Building on the ideas of Kahn (1990), Saks (2006) identified two types of personal engagement: job engagement and organisational engagement. Similarly, Schaufeli and Salanova (2011) stated that "employee engagement is a broader concept and may also include the relationship with the employee's professional or occupational role and with his or her organisation" (p. 40). Nevertheless, this study prefers to use work engagement, which some called job engagement (Saks, 2006) or work engagement (Schaufeli and Salanova, 2011), while Saks (2017) used the terms interchangeably.

Work engagement refers to "a positive, fulfilling work-related state of mind that is characterised by vigour, dedication, and absorption” (Schaufeli et al., 2006, p. 702). Vigour explains about individuals' high-level mental resilience and physical energy to perform the work role even in difficulties (Dollard and Bakker, 2010; Karadas and Karatepe, 2019). Dedication refers to individuals' affective belief in work role where they experience the sense of pride, enthusiasm, challenge and significance (Rabiul and Yean, 2021; Schaufeli and Salanova, 2011). Absorption, on the other hand, is about a pervasive and persistent state of mind concerning one's work role and the inability to detach from it (Bakker and Demerouti, 2017).

Organisational engagement refers to an individual's "role, responsibility, and tasks associated with one's membership in an organisation" (Saks, 2017, p. 79). Specifically, it describes the extent to which an employee engages in activities that are more related to organisational activities but not the work role (Saks, 2006; Schaufeli and Salanova, 2011). In other words, organisational engagement occurs due to employees' satisfaction, enthusiasm and commitment to the organisation (Kim and Koo, 2017).

\section{HR practices}

Two well-known HR practices included in the management literature are called "soft" and "hard" practices (Cregan et al., 2021; Jensen et al., 2011; Muthuku, 2020). Control-oriented or "hard" HR practices concentrate on controlling employees through the application of procedures and rules (Cregan et al., 2021; Gould-Williams and Davies, 2005; Jensen et al., 2011). Soft HR or commitment-oriented practices, on the other hand, focus on increasing employees' motivation and developing strong commitment towards organisations (Aktar and Pangil, 2018; Johari et al., 2013; Gurlek and Uygur, 2021). Soft HR practices provide high quality and flexible work performance by involving employees in the decision-making process, building trust in their managers and expressing concerns for employees (Elrehail et al., 2020; Gurlek and Uygur, 2021; Mowbray et al., 2020). Given the nature of the work environment in the hotel industry, the combination of both soft and hard HR practices may be more effective to engage employees in works rather than utilising them separately. 
Moreover, the collective efforts of HR practices will augment the effects on employees' psychological states, which then increases work engagement (Karadas and Karatepe, 2019; Kloutsiniotis and Mihail, 2020).

However, there is no universal specific set of HR practices that are suitable for every organisation (Kloutsiniotis and Mihail, 2020). Thus, this study proposes that soft HR practices could improve the psychological states of employees and foster greater work and organisational engagement (Agarwal and Farndale, 2017; Basit, 2017; Chen et al., 2016a; Elrehail et al., 2020; Gurlek and Uygur, 2021). HR practices (e.g. training and development, employee participation, rewards and cognition, career advancement, appraisal system, job security, recruitment process and teamwork) are vital for employees' growth (e.g. Alfes et al., 2020; Karadas and Karatepe, 2019; Mowbray et al., 2020; Murphy et al., 2018).

\section{HR practices and psychological states}

According to Saks and Gruman (2014), psychological meaningfulness "involves the extent to which people derive meaning from their work and feel that they are receiving a return on investments of self in the performance of their role” (p. 160). It refers to individuals' experiences at work that are meaningful, valuable and worthwhile (Fletcher and Schofield, 2019; Kahn, 1990). In general, individuals judge themselves by their job and their efforts (Edmondson, 1999; Steger et al., 2013). Work becomes meaningful once it facilitates individuals to achieve one or more elements of meaning, which matches the purpose of the individual such as personal growth, self-realisation, challenge, autonomy or competence (Edmondson and Lei, 2014; Fletcher and Schofield, 2019; Kahn, 1990).

The HR practices considered in this study are related to psychological meaningfulness. For example, training helps employees to develop necessary skills to further their career development (den Hartog et al., 2013). Other aspects, including employee participation in decision-making, are related to self-value; job security ensures career stability; and recruitment is related to self-realisation (den Hartog et al., 2013; Karadas and Karatepe, 2019). Appraisal, reward and recognition are related to increased social and socio-economic status, which could be psychologically meaningful (Elrehail et al., 2020). Teamwork also could enhance meaningfulness because of the collegiality among the team members and all are having similar purpose. In sum, combined HR practices might make employees to feel dignity and respect for their work which would likely generate meaningfulness. This is suggested by self-concept theory (Aryee et al., 2012; Shamir et al., 1993) which posits that individuals have a sense of experience of positive self-concept (meaningful work) due to having organisational supports (HR practices). Thus, we proposed:

H1. HR practices positively and significantly influence employees' psychological meaningfulness.

Kahn (1990) defined psychological safety is "as feeling able to show and employ one's self without fear of negative consequences to self-image, status, or career" (p. 708). It refers to a supportive, open and trustworthy work environment where employees feel safe to take risks and make trivial errors without fear of severe punishment (Rabiul et al., 2021; Lyu, 2016). This also means that employees who express their views openly to their superiors will not feel threatened with adverse consequences (Agarwal and Farndale, 2017; Dollard and Bakker, 2010; Edmondson, 1999). A psychologically safe environment will not affect employees' careers, self-image or status in harmful ways (Lyu, 2016).

HR practices (job security, training, appraisal, rewards, recruitment and teamwork) create a supportive work environment and remove insecurities and anxieties (Agarwal and Farndale, 2017; Edmondson, 1999). Some scholars in their meta-analyses (e.g. Carmeli and Gittell, 2009; Frazier et al., 2017) reveal that collective appropriate HR practices (e.g. appraisal, 
job security, training, rewards, recruitment, teamwork and participation) generate a sense of psychological safety at work by building relationships with employees. For example, through participation, employees can voice their opinions concerning future growth and career development opportunities to their superiors (Mowbray et al., 2020). All employees feel safe at work due to collective HR practices (training, recruitment process and teamwork) that help employees to focus on collective goals and avoid conflict (Agarwal and Farndale, 2017; Carmeli and Gittell, 2009; Frazier et al., 2017). Edmondson and Lei (2014) claim that employees will have a sense of security and establish positive relationships with their employers when their personal interests and future career development are adequately addressed. Positive attitudes towards HR practices generate psychological safety that leads to personal growth and development (Edmondson, 1999). All these HR practices generate psychological safety in different ways which is consistent with self-concept theory (Aryee et al., 2012). Therefore, it is proposed:

H2. HR practices positively and significantly influence employees' psychological safety at the workplace.

Kahn (1990) defined psychological availability as "individuals' sense of having the physical, emotional, or psychological resources to personally engage in a particular moment” (p. 714). May et al. (2004) further describe psychological availability as a persons' ability to perform work with cognitive, emotional and physical engagement. Positive supports from organisations such as training, career development opportunity, job security, appraisal, rewards and recognitions and fair recruitment process will develop self-concept that makes employees become confident of performing their work at any given situation (Gurlek and Uygur, 2021; Karadas and Karatepe, 2019).

HR practices play both an extrinsic and an intrinsic motivational role because they help employees grow actively by developing their skills and confidence, which makes them more psychologically available to perform the tasks (Bakker and Demerouti, 2017; Chen et al., 2016b; Karatepe and Karadas, 2019). Wang and Xu (2017) found that HR practices enhance employees' ability to perform tasks. For example, a proper recruitment system results in the hiring of capable employees. Moreover, feedback systems result in the recognition of employees' strengths and weaknesses, which can be developed through training. Employee participation, job security, teamwork, appraisal, rewards and recognition of good works provide intrinsic motivation and foster employees' psychological availability (Wang and $\mathrm{Xu}$, 2017; Zirar et al., 2020).

Overall, in line with self-concept theory (Aryee et al., 2012; Rabiul et al., 2021) that in a work environment where available appropriate HR practices (training, job security, appraisal, career advancement and rewards and recognition) are offered by the organisation, employees will display positive energy and psychological availability, either intrinsically or extrinsically (Karadas and Karatepe, 2019). Thus, we propose the following:

H3. HR practices positively and significantly influence employees' psychological availability.

\section{Psychological meaningfulness and employee engagement}

Meaningfulness is associated with a variety of personal and organisational consequences that are related to an employees' success at work (Mostafa and Abed El-Motalib, 2018; Steger et al., 2013). Low meaningfulness results in apathy and detachment (Fletcher and Schofield, 2019; May et al., 2004). In contrast, high meaningfulness results in high commitment and involvement towards the work (Chen et al., 2011). Psychologically meaningful work generates personal growth and satisfaction, which leads employees to be more committed to engage fully at work (Elrehail et al., 2020; Kunie et al., 2017; Steger et al., 2013). 
Meaningful work provides extrinsic and intrinsic motivation, which may influence employees to engage at work with full dedication, absorption and vigorousness. Several empirical studies confirmed that psychological meaningfulness is positively linked to employees' engagement at work and other positive employee outcomes (Fletcher and Schofield, 2019; May et al., 2004; Mostafa and Abed El-Motalib, 2018; Rabiul et al., 2021). Therefore, we propose:

H4-H5. Psychological meaningfulness positively and significantly influences (H4) work engagement and (H5) organisational engagement.

\section{Psychological safety and employee engagement}

In a psychologically safe work environment, individuals have a sense of confidence that they "will not be embarrassed, rejected, and punished by someone for speaking up" (Edmondson, 1999, p. 355). Without psychological safety, working environments are ambiguous, unpredictable and threatening (Kahn, 1990; May et al., 2004). Hence, employees may feel anxiety and fear in a situation in which they need to ask for help, feedback or propose ideas (Agarwal and Farndale, 2017; Dollard and Bakker, 2010; Edmondson, 1999; Kahn, 1990).

In contrast, Edmondson (1999) states that in psychologically safe environments, employees have "a sense of confidence that the team will not embarrass, reject, or punish someone for speaking up" (p. 354). As such, perceived psychological safety enhances interpersonal relationships among employees through a supportive, open, trustworthy, flexible and non-threatening environment (Rabiul et al., 2021; Lyu, 2016). In such an environment, employees have the opportunity to share their personal opinions to their superiors and build trust with senior management, which may lead to engagement at work (Harter et al., 2020; Kirk-Brown and Van Dijk, 2015; Robinson et al., 2004). A study by Basit (2017) of Malaysian hospital employees showed that psychological safety positively influenced work engagement. Accordingly, we propose:

H6-H7. Psychological safety positively and significantly influences (H6) work engagement and (H7) organisational engagement.

\section{Psychological availability and employee engagement}

Availability denotes an individual's belief of having physical, emotional and mental resources to perform the assigned tasks in a particular moment (Kahn, 1990). More specifically, it refers to the emotional, physical and psychological assets which an individual possesses that are required to do the job at any moment without interruption (Binyamin and Carmeli, 2010; May et al., 2004). Individuals' own evaluation of their personal resources (physical, emotional and mental) to perform the given tasks while considering various social distractions is also vital (Fletcher and Schofield, 2019; Kahn, 1990). Although physical availability varies, individuals' strength, stamina and flexibility could influence their workrelated engagement (Frazier et al., 2017; Edmondson, 1999). Moreover, individuals need to be both emotionally and mentally prepared for work. Kahn (1990) notes that without the positive feeling of having psychological availability, individuals are more probable to disengage from their appointed work roles. Therefore, we proposed the following:

H8-H9. Psychological availability positively and significantly influences (H8) work engagement and (H9) organisational engagement.

\section{Psychological states (meaningfulness, safety and availability) as the mediators between HR} practices and employee engagement

Training and development are among the facilities provided by various organisations to further grow employees' skills and abilities (Agarwal and Farndale, 2017). Employees with 
sufficient skills and knowledge will experience less anxiety and emotional exhaustion than their less-competent counterparts. This increases feelings of meaningfulness, safety and availability, which lead to stronger work and organisational engagement (Dollard and Bakker, 2010; Gurlek, 2020). Once employees experience these psychological states, they are more likely to engage at work (May et al., 2004). This is because employees who perceive their work as meaningful will have positive attitudes towards their future professional development; thus, they will work harder (Fletcher and Schofield, 2019).

Employee involvement in decision-making processes is another critical indicator of engagement as they feel valued by the organisations (Robinson et al., 2004). Moreover, employee involvement in decision-making creates opportunities to share ideas with superiors, which is positively associated with work engagement (Aon Hewitt, 2018; Robinson et al., 2004). Once an organisation offers a clear advancement process, employees' engagement and motivation at work become more meaningful (e.g. Aktar and Pangil, 2018; Ashton, 2017; Bakker and Demerouti, 2017; Huang et al., 2017). This is consistent with selfconcept theory (Aryee et al., 2012; Rabiul et al., 2021) - that positive support from HR practices is associated with the development of positive self-concept (meaningful work), which leads to greater work and organisation engagement.

Employees with perceived safety will be confident to perform works as they have sufficient skills and knowledge (Frazier et al., 2017) which can be done through training and development. Employees are committed at work, express a positive attitude and are satisfied owing to career advancement opportunities (Aktar and Pangil, 2018; Ashton, 2017; Huang et al., 2017). Job security is conceptualised as the degree to which employees expect to stay at their jobs over an extended period (Aktar and Pangil, 2018; Gould-Williams and Davies, 2005; Kirk-Brown and Van Dijk, 2015). Job security is an extrinsic factor that motivates employees to reach their full potential (Ashton, 2017; Bakker and Demerouti, 2017; Karadas and Karatepe, 2019). Having a secure job means employees will feel psychologically safe and engage in their work role (Aktar and Pangil, 2018; Kahn, 1990). Likewise, in line with selfconcept theory (Aryee et al., 2012; Rabiul et al., 2021) that individual employees may grow positive self-concept and confidence (psychological availability) to perform the job task having the appropriate HR practices from the organisation.

In sum, employee involvement, appraisal, career advancement opportunity, job security, training, development and rewards and recognition create psychological states of meaningfulness, safety and availability among employees that eventually lead to greater work and organisational engagement (Fletcher and Schofield, 2019; Kunie et al., 2017; May et al., 2004; Mostafa and Abed El-Motalib, 2018; Robinson et al., 2004). Hence, the following hypotheses were proposed:

H10-H11. Psychological meaningfulness mediates the link of HR practices and employees' (H10) work engagement and (H11) organisational engagement.

H12-H13. Psychological safety mediates the link of HR practices and employees' (H12) work engagement and (H13) organisational engagement.

H14-H15. Psychological availability mediates the link of HR practices and employees' (H14) work engagement and (H15) organisational engagement.

The research framework is shown in Figure 1.

\section{Method}

Measurements

Frontline hotel employees expressed their opinions about organisations' HR practices, facilities and their psychological states and work engagement based upon a continuous scale 


\section{EJMBE}

Figure 1 .

Conceptual model

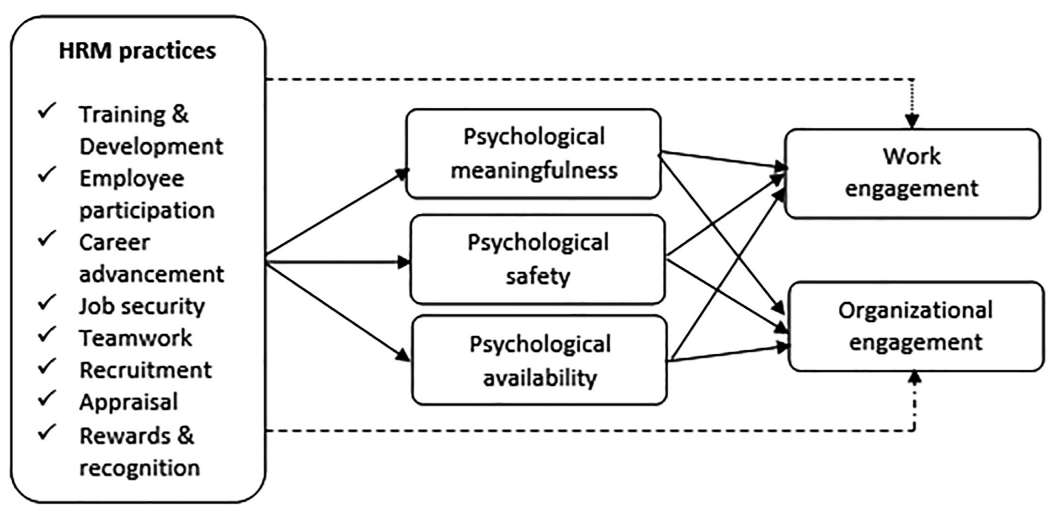

Note(s): (--) Solid indicates direct and (---) dotted line indicates indirect hypotheses

$(1=$ strongly disagree to $7=$ strongly agree $)$. Unidimensional HR practices (ten items) adapted from Jensen et al. (2011) and Gould-Williams and Davies (2005) were used. A sample item was, "I feel my job is secure in this hotel". Earlier researchers (den Hartog et al., 2013; Huang et al., 2017) found that this scale had good reliability.

Psychological meaningfulness (six items; sample item, "the work I do on this job is meaningful to me") and psychological availability (five items; sample item, "I am confident in my ability to deal with problems that come up at work") were adapted from May et al. (2004). These scales have shown good reliability and validity (Chen et al., 2011; Fletcher, 2016; Rabiul et al., 2021; May et al., 2004).

Edmondson (1999) developed a seven-item scale for psychological safety (sample item, "It is safe to take a risk in this team"). Chen et al. (2016a), Rabiul et al. (2021) and Wang et al. (2019) confirmed it had high reliability and validity.

Work engagement (nine items; sample item, "at my job, I feel strong and vigorous") was adapted from Schaufeli et al. (2006). Organisational engagement (six items; sample item, "I am highly engaged in this organization") was adapted from Saks (2006). Earlier studies (Fletcher and Schofield, 2019; Karadas and Karatepe, 2019; Rabiul and Yean, 2021; Saks, 2006) confirmed the reliability and validity of these scales.

\section{Sample and data collection}

This study surveyed full-time customer-contact frontline employees with a minimum of one year experience at five-star rated hotels in West Malaysia. According to the Ministry of Tourism, Arts and Culture (MOTAC) Malaysia, as of 14 June 2019, there are 107 five-star hotels (MOTAC, 2019). This study surveyed employees at 95 five-star hotels located in West Malaysia, following an earlier study by Kim and Koo (2017), to capture an adequate sample size and best represent the country's hotel industry. Customer-contact frontline employees in five-star hotels are more likely to have interactions with customers to maintain service standards (Kim and Koo, 2017). Of the 95 five-star hotels, 80 are located in six states including Kuala Lumpur $(n=31)$, Selangor $(n=16)$, Penang $(n=10)$, Melaka $(n=8)$, Pahang $(n=8)$ and Kedah $(n=7)$. After contacting HR departments for permission, we obtained positive responses from 43 hotels and continued with the data collection.

Given the unknown population in the Malaysian hotel industry, we employed Krejcie and Morgan's (1970) recommendations. They suggested that a sample size of 384 cases is adequate to test hypotheses for a population of $\geq 10,000,000$. Over 16 weeks - from June to 
September 2019, 900 survey questionnaires were distributed. In the first 11 weeks, we obtained 354 responses which were not enough with our expectation for further analysis; thus, we gave HR managers more time ( $3-5$ weeks) to seek additional responses. Finally, we obtained 549 responses over 16 weeks. After removing incomplete questionnaires, 434 valid and complete responses were analysed. We had a minimum of eight (8) responses and a maximum of 17 responses from a particular hotel, respectively.

Outlier, non-response bias, common method variance (CMV) and multicollinearity tests For outlier treatment, Mahalanobis distance was tested at the 0.001 significance level. The Mahalanobis distance test was 12.36, which is lower than Lynch's (2013) Chi-square $\left(x^{2}\right)$ distribution value of 18.47. Thus, no outliers were detected in the dataset. Additionally, non-response bias is a concern for social science research (Hair et al., 2014). The findings may not be generalisable if opinions differ substantially between the participants and non-participants (Armstrong and Overton, 1977). Hence, non-response bias was checked using Levene's test for equality variance (Hair et al., 2014). There was no significant difference between early (271 participants) and late (163 participants) responses.

Moreover, CMV is a concern in self-reported surveys; thus, various remedial procedures were adopted to lower the effects of CMV. First, to avoid potential bias, survey boxes were provided at every participating hotel to enable employees to submit completed questionnaires confidentially. Questionnaires were handed to participants directly by the researchers' own representatives rather than by HR staff. We also utilised statistical remedies to ensure CMV was not present in the data. The Harman single-factor test revealed that a single factor explained $26.83 \%$ of the total six-factor variance $64.73 \%$, which is much lower than the standard 50\%. Thus, no CMV existed in the dataset (Podsakoff and Organ, 1986). According to Hair et al. (2019), latent variables have no multicollinearity issues if the VIF values are less than 3.0 (see Table 1).

\section{Results}

Demographics of participants and descriptive statistics of variables

A total of 434 cases were valid (256 women, 59\%). All participants were Malaysian including 43\% Chinese-Malay, 39\% Malay, 10\% Indian-Malay, and the remaining 8\% were mixed races. Most participants had a minimum of one year to a maximum of seven years of experience: $12.4 \%$ were managerial level, $33 \%$ were supervisory level and $53 \%$ were general level. More than $47 \%$ of participants worked in the front of the hotel such as guest service assistants, front office executives and concierge. Nearly $30 \%$ worked in the food and beverage department. The remaining $23 \%$ of respondents were from sales, marketing and housekeeping departments. Table 2 illustrates that organisational engagement and psychological meaningfulness have the lowest and the highest mean values, respectively. Psychological availability has the highest correlation with work engagement.

\begin{tabular}{|c|c|c|c|c|c|c|c|}
\hline Variables & 1 & 2 & 3 & 4 & 5 & 6 & \\
\hline $\begin{array}{l}\text { 1. Psychological safety } \\
\text { 2. HR practices }\end{array}$ & 1.00 & & 1.00 & 1.00 & 1.187 & 1.187 & \\
\hline 3. Psychological meaningfulness & & & & & 1.312 & 1.312 & \\
\hline $\begin{array}{l}\text { 4. Psychological availability } \\
\text { 5. Work engagement } \\
\text { 6. Organizational engagement }\end{array}$ & & & & & 1.315 & 1.315 & $\begin{array}{r}\text { Table 1. } \\
\text { Inner variance inflation } \\
\text { factor }(\mathrm{VIF})\end{array}$ \\
\hline
\end{tabular}




\section{EJMBE}

Table 2.

Bivariate relationship, mean and standard deviation (SD)

\section{Measurement model}

It is necessary to evaluate the measurement model in PLS-SEM before hypothesis testing (Hair et al., 2019). Following recommendations by Cheah et al. (2018) concerning a reflective model, a consistent algorithm was performed in Smart-PLS. The results in Figure 2 indicate that all items were loaded between 0.476 and 0.945 and average variance extracted (AVE) ranged from 0.537 to 0.623 .

In line with Hair et al. (2014), 43 items were kept (see Figure 2) to fulfil the measurement requirements. The composite reliabilities (CRs) were as follows: HR practices (0.931), psychological safety (0.890), psychological meaningfulness (0.886), psychological availability (0.892), work engagement (0.921) and organisational engagement (0.901). Thus, convergent validity of the latent variables was confirmed to meet the following criteria: AVE $>0.50, \mathrm{CR}>0.70$ and loading $>0.40$ (Cheah et al., 2018; Hair et al., 2014).

Discriminant validity was confirmed through cross-loading, loading for individual items and heterotrait-monotrait (HTMT) ratio. Loading and cross-loading refer to the fact that indicator loading for primary constructs should be greater than the other constructs (Cheah et al., 2018; Hair et al., 2014). Table 3 indicates that the maximum value of the HTMT ratio was 0.479 , which is lower than the 0.85 suggested by Hair et al. (2019). Loading for the primary construct was higher than the other constructs; thus, discriminant validity was confirmed for all latent variables (Cheah et al., 2018).

\begin{tabular}{|c|c|c|c|c|c|c|c|c|}
\hline Variables & Mean & $\mathrm{SD}$ & 1 & 2 & 3 & 4 & 5 & 6 \\
\hline 1. HR practices & 4.515 & 1.217 & 1 & & & & & \\
\hline 2. Psychological meaningfulness & 5.366 & 0.965 & $0.127^{* *}$ & 1 & & & & \\
\hline 3. Psychological safety & 5.286 & 0.930 & $0.245^{* *}$ & $0.294^{* * *}$ & 1 & & & \\
\hline 4. Psychological availability & 4.957 & 1.179 & $0.233^{* *}$ & $0.396^{* *}$ & $0.300^{* *}$ & 1 & & \\
\hline 5. Work engagement & 4.968 & 1.058 & $0.336^{* *}$ & $0.382^{* *}$ & $0.324^{* *}$ & $0.434^{* *}$ & & \\
\hline 6. Organizational engagement & 4.662 & 1.364 & $0.208^{* *}$ & $0.237^{* *}$ & $0.246^{* *}$ & $0.261^{* *}$ & $0.333^{* *}$ & 1 \\
\hline
\end{tabular}

Note(s): $n=434$. ${ }^{* *}$. Correlation is significant at the 0.01 level (two-tailed)
Figure 2 .

Measurement model

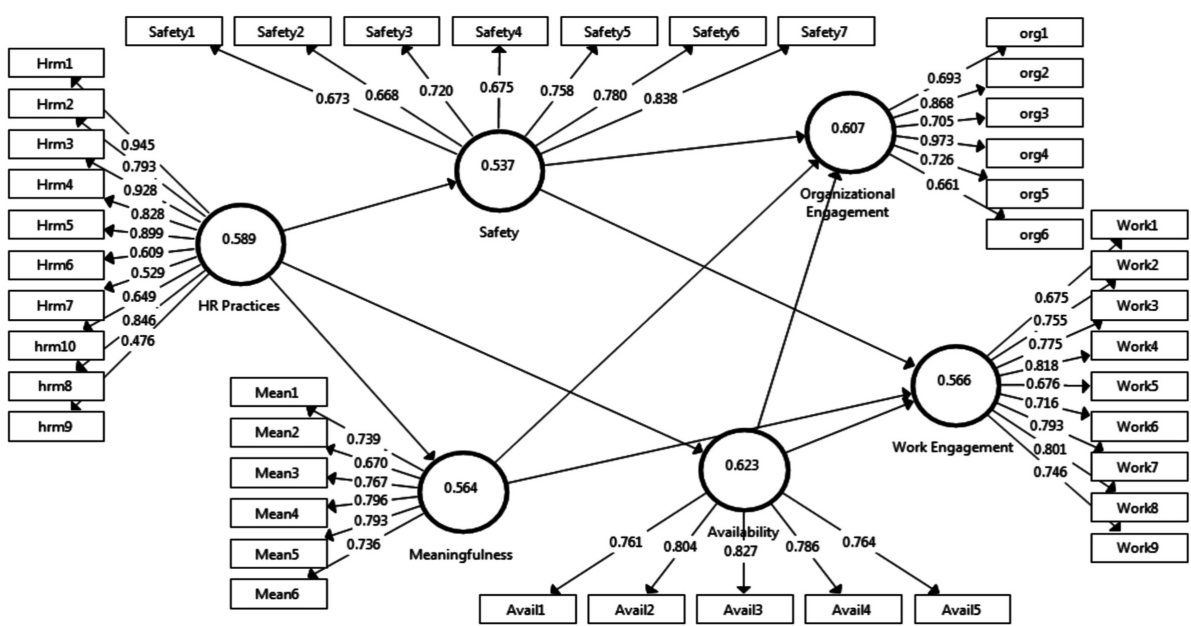


Fit indices

Blinding folding was applied to identify the predictive relevance $\left(Q^{2}\right)$. The results suggest that $Q^{2}$ is greater than zero; thus, the model has predictive power (Hair et al., 2014). The coefficients of determination $\left(R^{2}\right)$ were 0.302 for work engagement and 0.130 for organisational engagement. Accordingly, exogenous variables (three psychological states, HR practices) explained 30.2 and $13 \%$ of the variance in endogenous variables. $R^{2}$ values of $0.67,0.33$ and 0.19 are described as substantial, moderate and weak, respectively (Hair et al., 2019). Therefore, the model had a weak influence on endogenous variables.

\section{Structural model}

This Smart-PLS analysis employed consistent bootstrapping with more than 5,000 samples, following recommendations by Cheah et al. (2018). All nine direct hypotheses (H1-H9) and four indirect hypotheses (H12-H15) were supported (see Table 4 for $t$-value, $p$-values). For example, the findings indicate that HR practices positively influence meaningfulness $(\beta=0.147, p<0.01)$, safety $(\beta=0.272, p<0.001)$ and availability $(\beta=0.262, p<0.001)$ in employees. However, only H10 and H11 were not supported (see Table 4 for $t$-values and $p$-values).

\section{Discussion and conclusion}

As anticipated by self-concept theory (Aryee et al., 2012; Shamir et al., 1993), appropriate HR practices promote positive self-concept (meaningfulness, safety and availability) among employees. Although these three psychological states are significant predictors of employee engagement, meaningfulness did not have the mediation influence that safety and availability did.

As expected, H1-H3 were supported. Once employees received training, career development opportunities, rewards, feedback opportunities, and there was a fair recruitment process, they looked at their work as meaningful and safe (Agarwal and Farndale, 2017; Chen et al., 2016a; Kirk-Brown and Van Dijk, 2015). Moreover, HR facilities also develop confidence among employees to perform their work roles (Binanmin and Carmeli, 2010).

Likewise, as anticipated, H4-H9 were supported. Meaningfulness, safety and availability positively influence work engagement and organisational engagement. Several studies have confirmed that employees' perception of a psychologically safe work environment, meaningful work and available personal resources promote positive employee behaviour such as greater organisational and work engagement (Chen et al., 2011; Fletcher, 2016; Fletcher and Schofield, 2019; Memon et al., 2020).

Concerning mediation, contradictory to earlier expectation, psychological meaningfulness did not mediate the link between HR practices and work engagement nor organisational

\begin{tabular}{|c|c|c|c|c|c|c|c|c|}
\hline & Variables & 1 & 2 & 3 & 4 & 5 & 6 & \\
\hline 1 & Psychological safety & & & & & & & \\
\hline 2 & HR practices & 0.269 & & & & & & \\
\hline 3 & Psychological meaningfulness & 0.332 & 0.140 & & & & & \\
\hline 4 & Psychological availability & 0.337 & 0.257 & 0.444 & & & & Table 3. \\
\hline 5 & Work engagement & 0.357 & 0.365 & 0.422 & 0.479 & & & HTMT (heterotrait- \\
\hline 6 & Organizational engagement & 0.273 & 0.227 & 0.264 & 0.292 & 0.366 & & monotrait) ratio \\
\hline
\end{tabular}

Linking human resources practices 
EJMBE

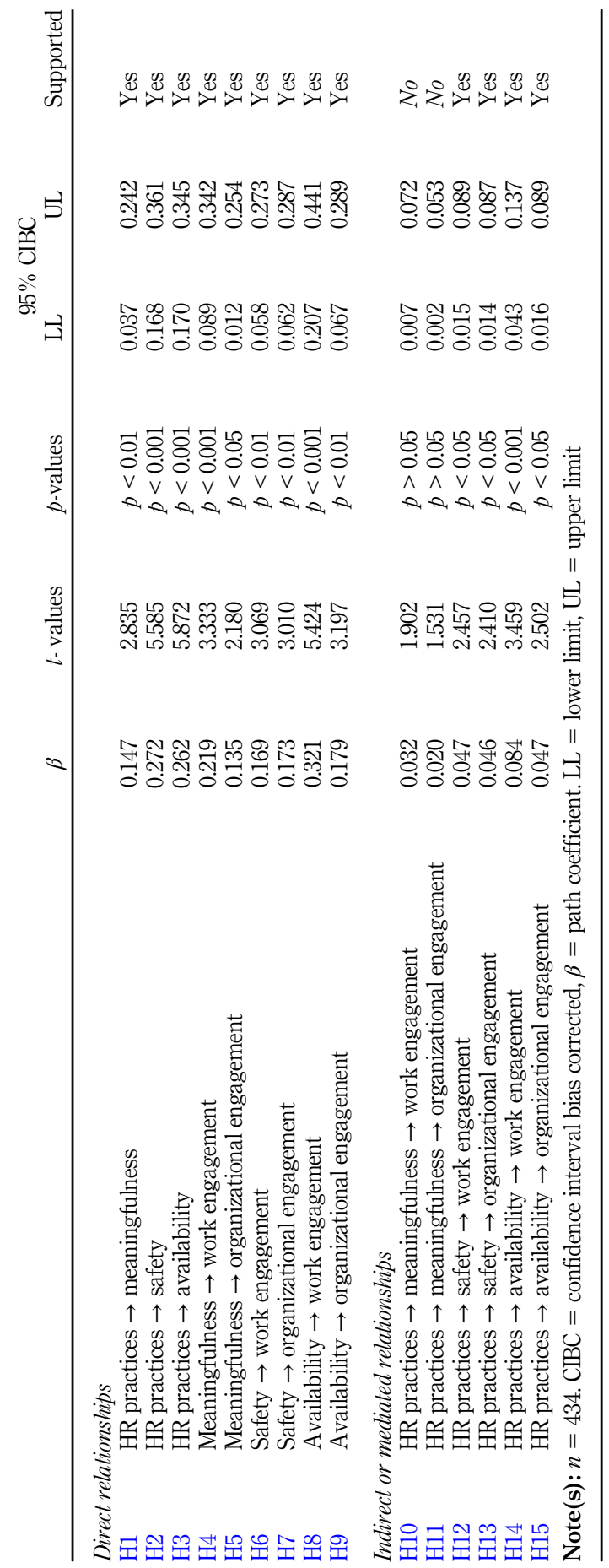

Table 4.

Direct and indirect relationships 
engagement. Thus, H10 and H11 were not supported. According to Steger et al. (2013) and Rabiul et al. (2021), meaningfulness differs from one person to another owing to the differences in their expectations and lifelong planning. For example, HR practices may not always facilitate meaningfulness among employees. Moreover, meaningful work is linked to intrinsic and extrinsic motivation and individuals' weaknesses and strengths (Fletcher and Schofield, 2019).

As anticipated, H12-H15 were supported. Psychological safety mediates the effects of HR practices on both work engagement and organisational engagement. Similarly, psychological availability also mediated the link between HR practices and work engagement and organisational engagement. So far, only a limited number of studies have investigated the roles of psychological safety and availability as mediating mechanisms between HR practices and work and organisational engagement. According to self-concept theory (e.g. Mostafa and El-Motalib, 2018; Shamir et al., 1993), employees who received supportive HR practices experienced positive influences on their self-concept; therefore, they had increased confidence to perform their job duties (Bakker and Demerouti, 2017; Kahn, 1990).

\section{Theoretical contributions}

The above findings contribute to self-concept theory (Shamir et al., 1993) in which employees' perceived appropriate HR practices act as the catalyst for creating psychological states of meaningfulness, safety and availability. The findings validate earlier investigations (e.g. Agarwal and Farndale, 2017; Binyamin and Carmeli, 2010; Chen et al., 2016a; Wang et al., 2019) in the hotel industry in Malaysia. This contributes to self-concept theory (Shamir et al., 1993) that appropriate HR practices promote one's positive self-concept about their work role, workplace safety and their work-related confidence.

Meaningfulness, safety and availability were significant predictors of organisational and work engagement. To our knowledge, our study is the first to investigate these three psychological states and positively link them to organisational engagement. Thus, this study validates Kahn's (1990) belief that psychological states are the prerequisite of engaging employees at both the work and organisational level, in the Asian context.

Our findings also contribute to the HR literature by establishing psychological states as the underlying mechanisms among the relationships between HR practices and employee engagement. This study has successfully extended the self-concept theory. Individuals' positive self-concept is generated by available appropriate HR practices by organisation, which in turn generates positive work behaviour in a motivational way.

\section{Practical implications}

Concerning practical implications, hospitality organisations need to focus on appropriate HR practices in the hotel industry in Malaysia. Training and personal development, recruitment processes, career opportunities, involving employees in decision-making and providing rewards for good work are key measures to enhance employees' perceptions of availability, safety and meaningfulness in the workplace. It is important for hoteliers to provide the above facilities with proper policy implementation. In fact, these psychological states have a key impact on both organisational and work engagement. Highly engaged employees often display less turnover intention, deliver better customer service, have better financial performance, experience less job stress and display healthy psychological well-being as compared to their counterparts (Harter et al., 2020; Gallup, 2017; Memon et al., 2020).

Hospitality organisations could design the workplace to make it more meaningful and safer by aligning with employees' interests. Individuals' mental, physical and emotional confidence are important for them to provide better customer service. Rewards and recognition might enhance emotional well-being and foster performance (Johari et al., 2013; 
Xu et al., 2020). Employees may feel emotionally drained and detached from their work if there is a lack of available resources (Karadas and Karatepe, 2019; Wang and Xu, 2017). Training can help them improve their knowledge, skills, and capacities - allowing them to perform their duties more efficiently (Alfes et al., 2020). Psychological availability has been linked to individuals' resiliency and ability to perform work efficiently (Agarwal and Farndale, 2017; Binyamin and Carmeli, 2010; Muthuku, 2020). Therefore, hoteliers should enhance employees' individual capacity or self-belief to perform tasks through training and recruiting the right people.

Hoteliers need to implement an appropriate bundle of HR practices to keep employees engaged by developing meaningfulness of work, make them available to perform their work roles by utilising training and career opportunities, retain talented employees through reward and recognition and motivate them by allowing them to participate in decision-making processes (Wang and Xu, 2017; Xu et al.,2020; Zirar et al., 2020). The importance of this is even more explicit in a service-driven hospitality profession. When staff are given the authority to interact with consumers, they have the option to choose how to handle a wide range of requirements, wants, expectations and complaints (Chen et al., 2016b; Gurlek, 2020).

Since psychological safety is a precondition of employee engagement, HR professionals need to ensure the work environment is safe (Carmeli and Gittell, 2009; Fletcher, 2016), which promotes job security and career advancement (Wang et al., 2019). Managers' clarification of work roles, social support, fairness and justice could enhance work environment safety (Jensen et al., 2011; Lyu, 2016; Rabiul et al., 2021; Wang et al., 2019). Frontline employees frequently have interactions with customers; therefore, managers should encourage them to participate in how to provide better customer service (Mowbray et al., 2020).

\section{Limitations and future research directions}

This study had some limitations. First, the findings are limited to five-star quality hotels in Malaysia. Therefore, findings concerning lower-level hotels and other industries may differ. In addition, the cross-sectional design hinders our ability to infer causation; therefore, future studies may wish to use a longitudinal design. Moreover, psychological states may depend on a variety of things and differ from person to person. Therefore, future research should include socio-emotional, economic and physical resources that might influence psychological states that are related to work behaviours. Limited studies have been conducted on the relationship between psychological states and organisational engagement. Future studies should aim to replicate our findings in other industries and investigate the factors that promote meaningfulness at work, such as leadership, HR practices or other contextual factors. Additionally, replicating the study including all types of hotels during the COVID-19 pandemic could help understand the possible influence of the pandemic on the psychological factors.

\section{References}

Agarwal, P. and Farndale, E. (2017), "High-performance work systems and creativity implementation: the role of psychological capital and psychological safety", Human Resource Management Journal, Vol. 27 No. 3, pp. 440-458.

Aktar, A. and Pangil, F. (2018), "Mediating role of organizational commitment in the relationship between human resource management practices and employee engagement", International Journal of Sociology and Social Policy, Vol. 38 Nos 7-8, pp. 606-636.

Alfes, K., Veld, M. and Fürstenberg, N. (2020), "The relationship between perceived highperformance work systems, combinations of human resource well-being and human resource performance attributions and engagement”, Human Resource Management Journal, Vol. 31 No. 3, pp. 729-752. 
Armstrong, J.S. and Overton, T.S. (1977), "Estimating nonresponse bias in mail surveys", Journal of Linking human Marketing Research, Vol. 14 No. 3, pp. 396-402.

Aryee, S., Walumbwa, F.O., Zhou, Q. and Hartnell, C.A. (2012), "Transformational leadership, innovative behaviour, and task performance: test of mediation and moderation processes", Human Performance, Vol. 25 No. 1, pp. 1-25.

Ashton, A.S. (2017), "How human resources management best practice influence employee satisfaction and job retention in the Thai hotel industry", Journal of Human Resources in Hospitality and Tourism, Vol. 17 No. 2, pp. 175-199.

Aon Hewitt (2018), "2018 trends in global employee engagement global employee engagement rebounds to match its all-time high", available at: http://images.transcontinentalmedia.com/ LAF/lacom/Aon_2018_Trends_In_Global_Employee_Engagement.pdf.

Bakker, A.B. and Demerouti, E. (2017), "Job demands-resources theory: taking stock and looking forward”, Journal of Occupational Health Psychology, Vol. 22 No. 3, pp. 273-285.

Basit, A.A. (2017), "Trust in supervisor and job engagement: mediating effects of psychological safety and felt obligation", The Journal of Psychology, Vol. 151 No. 8, pp. 701-721.

Binyamin, G. and Carmeli, A. (2010), "Does structuring of human resource management processes enhance employee creativity? The mediating role of psychological availability", Human Resource Management, Vol. 49 No. 6, pp. 999-1024.

Carmeli, A. and Gittell, J.H. (2009), "High-quality relationships, psychological safety, and learning from failures in work organizations", Journal of Organizational Behavior, Vol. 30 No. 6, pp. 709-729.

Cheah, J.H., Memon, M.A., Chuah, F. and Ting, H. (2018), "Assessing reflective models in marketing research: a comparison between pls and plsc estimates", International Journal of Business and Society, Vol. 19 No. 1, pp. 139-160.

Chen, Z.J., Zhang, X. and Vogel, D. (2011), "Exploring the underlying processes between conflict and knowledge sharing: a work-engagement Perspective 1", Journal of Applied Social Psychology, Vol. 41 No. 5, pp. 1005-1033.

Chen, S., Zhang, G., Zhang, A. and Xu, J. (2016a), “Collectivism-oriented human resource management and innovation performance: an examination of team reflexivity and team psychological safety - Corrigendum”, Journal of Management and Organization, Vol. 22 No. 4, p. 549.

Chen, M., Lyu, Y., Li, Y., Zhou, X. and Li, W. (2016b), "The impact of high-commitment HR practices on hotel employees' proactive customer service performance", Cornell Hospitality Quarterly, Vol. 58 No. 1, pp. 94-107.

Cregan, C., Kulik, C.T., Johnston, S. and Bartram, T. (2021), "The influence of calculative ('hard') and collaborative ('soft') HRM on the layoff-performance relationship in high performance workplaces", Human Resource Management Journal, Vol. 31 No. 1, pp. 202-224.

den Hartog, D.N., Boon, C., Verburg, R.M. and Croon, M.A. (2013), "HRM, communication, satisfaction, and perceived performance", Journal of Management, Vol. 39 No. 6, pp. 1637-1665.

Dollard, M.F. and Bakker, A.B. (2010), "Psychosocial safety climate as a precursor to conducive work environments, psychological health problems, and employee engagement", Journal of Occupational and Organizational Psychology, Vol. 83 No. 3, pp. 579-599.

Edmondson, A. (1999), "Psychological safety and learning behavior in work teams", Administrative Science Quarterly, Vol. 44 No. 2, pp. 350-383.

Edmondson, A.C. and Lei, Z. (2014), "Psychological safety: the history, renaissance, and future of an interpersonal construct”, Annual Review of Organizational Psychology and Organizational Behavior, Vol. 1 No. 1, pp. 23-43.

Elrehail, H., Harazneh a, I., Abuhjeeleh, M., Alzghoul, A., Alnajdaw, S. and Ibrahim, H.M. (2020), "Employee satisfaction, human resource management practices and competitive advantage the case of Northern Cyprus", European Journal of Management and Business Economics, Vol. 29 No. 2, pp. 125-149. 
Fletcher, L. (2016), "How can personal development lead to increased engagement? The roles of meaningfulness and perceived line manager relations", The International Journal of Human Resource Management, Vol. 30 No. 7, pp. 1203-1226.

Fletcher, L. and Schofield, K. (2019), "Facilitating meaningfulness in the workplace: a field intervention study", The International Journal of Human Resource Management, pp. 1-29.

Frazier, M.L., Fainshmidt, S., Klinger, R.L., Pezeshkan, A. and Vracheva, V. (2017), "Psychological safety: a meta-analytic review and extension”, Personnel Psychology, Vol. 70 No. 1, pp. 113-165.

Gallup (2017), "State of the global workplace", available at: http://www.managerlenchanteur.org/wpcontent/uploads/Gallup-State-of-the-Global-Workplace-Report-2017_Executive-Summary.pdf.

Gould-Williams, J. and Davies, F. (2005), "Using social exchange theory to predict the effects of hrm practice on employee outcomes", Public Management Review, Vol. 7 No. 1, pp. 1-24.

Guan, X. and Frenkel, S. (2018), "How HR practice, work engagement and job crafting influence employee performance", Chinese Management Studies, Vol. 12 No. 3, pp. 591-607.

Gurlek, M. (2020), "Effects of high-performance work systems (HPWSs) on intellectual capital, organizational ambidexterity and knowledge absorptive capacity: evidence from the hotel industry", Journal of Hospitality Marketing and Management, Vol. 30 No. 1, pp. 38-70.

Gurlek, M. and Uygur, A. (2021), "Service-oriented high-performance human resource practices and employee service performance: a test of serial mediation and moderation models", Journal of Management and Organization, Vol. 27 No. 1, pp. 197-233.

Hair, J.F., Black, W.C., Babin, B.J. and Anderson, R.E. (2014), Multivariate Data Analysis, Pearson New International Edition, 7th ed., Pearson Higher, New York, NY.

Hair, J.F., Risher, J.J., Sarstedt, M. and Ringle, C.M. (2019), "When to use and how to report the results of PLS-SEM", European Business Review, Vol. 31 No. 1, pp. 2-24.

Harter, J. and Rubenstein, K. (2020), "The 38 most engaged workplaces in the world put people first", available at: https://www.gallup.com/workplace/290573/engaged-workplaces-world-put-peoplefirst.aspx.

Harter, J.K., Schmidt, F.L., Agrawal, S., Blue, A., Plowman, S.K., Josh, P. and Asplund, J. (2020), The Relationship between Engagement at Work and Organizational Outcomes 2020, Q12® MetaAnalysis, Gallup.

Huang, Y., Ma, Z. and Meng, Y. (2017), "High-performance work systems and employee engagement: empirical evidence from China", Asia Pacific Journal of Human Resources, Vol. 56 No. 3, pp. 341-359.

Hyland, M.E. (1990), “A functional theory of illness”, in Baker, W.J., Hyland, M.E., van Hezewijk, R. and Terwee, S. (Eds), Recent Trends in Theoretical Psychology. Recent Research in Psychology, Springer, New York, NY.

Jensen, J.M., Patel, P.C. and Messersmith, J.G. (2011), "High-performance work systems and job control: consequences for anxiety, role overload, and turnover intentions", Journal of Management, Vol. 39 No. 6, pp. 1699-1724.

Johari, J., Adnan, Z., Yean, T.F., Yahya, K.Y. and Isa, S.N. (2013), "Fostering employee engagement through human resource practices: a case of manufacturing firms in Malaysia", Jurnal Pengurusan, Vol. 38 No. 1, pp. 15-26.

Kahn, W.A. (1990), "Psychological conditions of personal engagement and disengagement at work", Academy of Management Journal, Vol. 33 No. 4, pp. 692-724.

Karadas, G. and Karatepe, O.M. (2019), "Unraveling the black box: the linkage between highperformance work systems and employee outcomes”, Employee Relations, Vol. 41 No. 1, pp. 67-83.

Kim, M. and Koo, D. (2017), "Linking LMX, engagement, innovative behavior, and job performance in hotel employees", International Journal of Contemporary Hospitality Management, Vol. 29 No. 12 , pp. 3044-3062. 
Kirk-Brown, A. and Van Dijk, P. (2015), "An examination of the role of psychological safety in the relationship between job resources, affective commitment and turnover intentions of Australian employees with chronic illness", The International Journal of Human Resource Management, Vol. 27 No. 14, pp. 1626-1641.

Kloutsiniotis, P.V. and Mihail, D.M. (2020), "The effects of high performance work systems in employees' service-oriented OCB”, International Journal of Hospitality Management, Vol. 90 No. 1, pp. 1-12.

Krejcie, R.V. and Morgan, D.W. (1970), "Determining sample size for research activities”, Educational and Psychological Measurement, Vol. 30 No. 3, pp. 607-610.

Kunie, K., Kawakami, N., Shimazu, A., Yonekura, Y. and Miyamoto, Y. (2017), "The relationship between work engagement and psychological distress of hospital nurses and the perceived communication behaviors of their nurse managers: a cross-sectional survey", International Journal of Nursing Studies, Vol. 71 No. 1, pp. 115-124.

Lynch, S.M. (2013), Using Statistics in Social Research: A Concise Approach, Springer Science \& Business Media, London.

Lyu, X. (2016), "Effect of organizational justice on work engagement with psychological safety as a mediator: evidence from China", Social Behavior and Personality: An International Journal, Vol. 44 No. 8, pp. 1359-1370.

May, D.R., Gilson, R.L. and Harter, L.M. (2004), "The psychological conditions of meaningfulness, safety and availability and the engagement of the human spirit at work", Journal of Occupational and Organizational Psychology, Vol. 77 No. 1, pp. 11-37.

Memon, M.A., Salleh, R., Mirza, M.Z., Cheah, J., Ting, H., Ahmad, M.S. and Tariq, A. (2020), "Satisfaction matters: the relationships between HRM practices, work engagement and turnover intention", International Journal of Manpower, Vol. 42 No. 1, pp. 21-50.

Mostafa, A.M. and Abed El-Motalib, E.A. (2018), "Ethical leadership, work meaningfulness, and work engagement in the public sector", Review of Public Personnel Administration, Vol. 40 No. 1, pp. 112-131.

MOTAC (2019), "Rated tourist accommodation premises", available at: https://www.motac.gov.my/en/ check/hotel? $\mathrm{s}=\& \mathrm{n}=3 \& \mathrm{v}=40$.

Mowbray, P.K., Wilkinson, A. and Tse, H.H. (2020), "High-performance work systems and employee voice behaviour: an integrated model and research agenda", Personnel Review, Vol. 50 No. 6, pp. 1530-1543, doi: 10.1108/pr-12-2019-0692.

Murphy, K., Torres, E., Ingram, W. and Hutchinson, J. (2018), "A review of high performance work practices (HPWPs) literature and recommendations for future research in the hospitality industry", International Journal of Contemporary Hospitality Management, Vol. 30 No. 1, pp. 365-388.

Muthuku, M. (2020), "Soft HRM model: human capital as the greatest asset for organizational performance", Journal of Human Resource and Leadership, Vol. 4 No. 2, pp. 14-29.

Podsakoff, P.M. and Organ, D.W. (1986), "Self-reports in organizational research: problems and prospects", Journal of Management, Vol. 12 No. 4, pp. 531-544.

Rabiul, M.K. and Yean, T.F. (2021), "Leadership styles, motivating language, and work engagement: an empirical investigation of the hotel industry", International Journal of Hospitality Management, Vol. 92 No. 1, pp. 1-10.

Rabiul, M.K., Patwary, A.K., Mohamed, A.E. and Rashid, H.O. (2021), "Leadership styles, psychological factors, and employee commitment to service quality in the hotel industry", Journal of Quality Assurance in Hospitality and Tourism, pp. 1-29, doi: 10.1080/1528008x.2021. 1913695.

Robinson, D., Perryman, S. and Hayday, S. (2004), "The drivers of employee engagement (408)", Institute for Employment Studies website, available at: http://www.employment-studies.co.uk/ system/files/resources/files/408.pdf. 
Saks, A.M. (2006), “Antecedents and consequences of employee engagement”, Journal of Managerial Psychology, Vol. 21 No. 7, pp. 600-619.

Saks, A.M. (2017), "Translating employee engagement research into practice", Organizational Dynamics, Vol. 2 No. 46, pp. 76-86.

Saks, A.M. and Gruman, J.A. (2014), "What do we really know about employee engagement?", Human Resource Development Quarterly, Vol. 25 No. 2, pp. 155-182.

Schaufeli, W. and Salanova, M. (2011), "Work engagement: on how to better catch a slippery concept", European Journal of Work and Organizational Psychology, Vol. 20 No. 1, pp. 39-46.

Schaufeli, W.B., Bakker, A.B. and Salanova, M. (2006), "The measurement of work engagement with a short questionnaire", Educational and Psychological Measurement, Vol. 66 No. 4, pp. 701-716.

Shamir, B., House, R.J. and Arthur, M.B. (1993), "The motivational effects of charismatic leadership: a self-concept-based theory", Organization Science, Vol. 4 No. 4, pp. 577-594.

Steger, M.F., Littman-Ovadia, H., Miller, M., Menger, L. and Rothmann, S. (2013), "Engaging in work even when it is meaningless", Journal of Career Assessment, Vol. 21 No. 2, pp. 348-361.

The Star (2019), "Tourism contributes RM42bil to economy", The Star, available at: https://www. thestar.com.my/business/business-news/2019/08/24/tourism-contributes-rm42bil-to-economy .

Trading Economics (2020), "Malaysia tourism revenues | 1998-2019 data | 2020-2022 forecast | Historical | Chart", available at: https://radingeconomics.com/malaysia/tourism-revenues.

Wang, Z. and Xu, H. (2017), "How and when service-oriented high-performance work systems foster employee service performance", Employee Relations, Vol. 39 No. 4, pp. 523-540.

Wang, X., Guchait, P., Lee, J. and Back, K. (2019), "The importance of psychological safety and perceived fairness among hotel employees: the examination of antecedent and outcome variables", Journal of Human Resources in Hospitality and Tourism, Vol. 18 No. 4, pp. 504-528.

Xu, J., Xie, B. and Tang, B. (2020), “Guanxi HRM practice and employees' occupational well-being in China: a multi-level psychological process", International Journal of Environmental Research and Public Health, Vol. 17 No. 7, pp. 1-15.

Zhang, L., Zhang, Y., Dallas, M., Xu, S. and Hu, J. (2018), "How perceived empowerment HR practices influence work engagement in social enterprises - a moderated mediation model", The International Journal of Human Resource Management, Vol. 29 No. 20, pp. 2971-2999.

Zirar, A., Trusson, C. and Choudhary, A. (2020), "Towards a high-performance HR bundle process for lean service operations", International Journal of Quality and Reliability Management, Vol. 38 No. 1, pp. 25-45.

\section{Corresponding author}

Md Karim Rabiul can be contacted at:mdkrabiul@gmail.com

For instructions on how to order reprints of this article, please visit our website:

www.emeraldgrouppublishing.com/licensing/reprints.htm

Or contact us for further details: permissions@emeraldinsight.com 